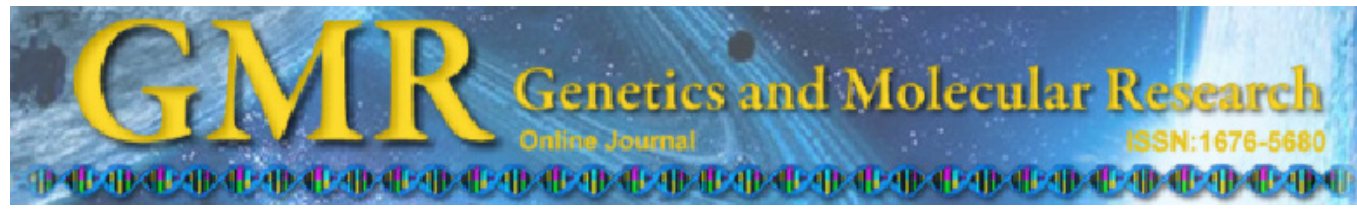

Short Communication

\title{
Cross-species amplification of selected zebrafish, central stoneroller, and finescale dace microsatellites in lake minnow populations
}

\author{
D. Kaczmarczyk \\ Department of Environmental Biotechnology, \\ University of Warmia and Mazury, Olsztyn, Poland \\ Corresponding author: D. Kaczmarczyk \\ E-mail:kaczmarczyk@uwm.edu.pl
}

Genet. Mol. Res. 12 (1): 154-159 (2013)

Received March 14, 2012

Accepted July 20, 2012

Published January 24, 2013

DOI http://dx.doi.org/10.4238/2013.January.24.7

\begin{abstract}
Fifteen sets of PCR primers designed for the amplification of microsatellite loci from Danio rerio and Phoxinus neogaeus Campostoma DNA that have been proven applicable for molecular studies of several species of cyprinids were tested for amplification of microsatellites from lake minnow DNA. The samples were taken from 298 fish inhabiting 6 distinct populations located in Poland, and DNA was extracted from dried fin clips. There were 6 sets of primer loci that were identified as useful for amplification of microsatellites from lake minnow DNA, which were polymorphic and could be applied in population genetics of this species. Three other sets of primers provided PCR products with a considerable number of stutter bands obscuring the identity of true microsatellite alleles. The amplification of lake minnow microsatellites using the 6 remaining primer sets was unsuccessful.
\end{abstract}

Key words: Cross-species amplification; Lake minnows; Microsatellites 


\section{INTRODUCTION}

The lake minnow (Eupallasella percnurus) is a small cyprinid fish listed in the Red Book of endangered species, and is facing extinction in Poland. It is protected under the Natura 2000 program (Radtke et al., 2011). The conservation of this species is promoted by several methods (Wolnicki et al., 2011), including the transfer of fish or enhancement of existing populations with hatchery-produced juveniles. These techniques have been accompanied by efforts focused on conservation of the biodiversity specific for lake minnow populations present in Poland. The successful conservation and management of lake minnow populations requires an assessment of the level of genetic variability specific to lake minnow populations and an assessment of the observed genetic differences between the populations. The assessment of genetic variations can be based on polymorphism of microsatellite loci, also known as simple short repeats (SSRs). This technique has been successfully applied in the management of resources of many endangered fish species (Zhao et al., 1996; O'Connell and Wright, 1997; Spruell et al., 2003) and can be applied for lake minnow.

Microsatellites are known as markers specific for given species or groups of species, enabling their identification (Fopp-Bayat, 2002), but several studies have shown that flanking sequences of microsatellites might be conserved well enough through evolution to serve as primer-annealing sites for closely related species (Primmer et al., 1996; Tong et al., 2002), therefore enabling cross-species amplification. The taxonomy and genetics of the lake minnow are unclear and mostly unknown. In available publications there are no primer sequences designed for amplification of lake minnow microsatellites or reports describing the successful amplification through application of sets of primers taken from other cyprinid species. In this study, we attempted to identify the sets of primers that could be useful in the amplification of microsatellites from lake minnow DNA by testing a group of primer sets that are known to be common for several cyprinids.

\section{MATERIAL AND METHODS}

\section{Material}

Fin clips (approximately $25 \mathrm{~mm}^{2}$ in size) were taken from 298 fish inhabiting 6 lake minnow populations in various regions of Poland [Bledzewo, Kowalicha, Siedliszcze, Sosniak, Mikolajki Pomorskie (Mikolajki Pom.), and Podpakule]. Approximately 50 fish from each population were investigated.

\section{DNA extraction}

Genomic DNA was extracted and purified from the fin tissues using a Sherlock AX DNA Extraction and Purification Kit and Genomic Mini AX Tissue SPIN DNA Extraction and Purification Kit (A\&A Biotechnology, Poland). The extraction procedure was performed following manufacturer recommendations. DNA samples were stored at a temperature of $-20^{\circ} \mathrm{C}$. The integrity of the DNA samples was visually inspected after electrophoresis on $1.5 \%$ agarose gel stained with ethidium bromide. All gels were photographed using a gel imaging system and the pictures were digitally recorded. Samples of the DNA yields were quantified by 
spectrophotometric analysis. Only samples containing more than $30 \mu \mathrm{g} / \mathrm{mL}$ double-stranded DNA were qualified for the PCR stage.

\section{Selection of the primer sets}

The primer sets Z8356, Z9068, Z9523, Z9878, Z10363, Z11841, Z13419, Z14008 were designed for zebrafish (Danio rerio) (Shimoda et al., 1999) and their sequences were taken from http://www.ncbi.nlm.nih.gov. The primer sets $C A 3, C A 4, C A 5, C A 11$, and $C A 12$ were designed for central stoneroller (Campostoma anomalum) and their sequences were taken from Dimsoski et al. (2000). The primer set Phox 23 was designed for finescale dace (Phoxinus neogaeus) and its sequence was taken from GenBank (accession No. FJ807698). The sequence of primer Phox30 was the same as in set Phox23, but both oligonucleotides were shortened at 3 ' at one nucleotide. From among the sets of primers tested by Holmen et al. (2005) in crosspiece amplification of the microsatellites from DNA of various cyprinid fish, we selected those which provided polymorphic, high-quality PCR product across a wide range of investigated species, including Phoxinus phoxinus, the other minnow species inhabiting streams in Poland. The investigated primer sets and their sequences are given in Table 1.

Table 1. List of primer sequences taken from zebra fish $(Z)$, central stoneroller $(C a)$, and finescale dace (Phox) tested for amplification of microsatellites from lake minnow DNA.

\begin{tabular}{lll}
\hline Locus & Forward primer (5'-3') & \\
\hline$Z 8356$ & Reverse primer (5'-3') \\
$Z 9068$ & AACAGGGGGGCAAATAATTC & GTTCCACACAATCGACATGTG \\
$Z 9523$ & TGCGCTTCATCCTCTACTAAA & GTGAGCTGCTGCCCTGTG \\
$Z 9878$ & ACTGCTTTGGCAGCTGTGC \\
$Z 10362$ & AAACCTGTAATGGGACAGCC & CACGTCATCAAGCAGAGGAA \\
$Z 11841$ & ACATCCACACCGTCTGTCAA & AGCTACTGAAACCCTTTGGC \\
$Z 13419$ & GGCACGTAAAAGCGGTTTAA \\
$Z 14008$ & GGTGACCTCATGGAAGCATT & CATGTGAACTCTGAAGCCCA \\
Ca3 & TTCTGTCACCTGCAGTTTGC & CTGAACATTCAAGCGTTCGA \\
Cas & AGGTTCAGAGCCCTCATCA & TCTAGCCCCCAAATTTACGG \\
Call & ATTCAGCCGTGGAGAAAGAC & AACAGCGCGAGCGTCATTC \\
Cal2 & GGACAGTGAGGGACGCAGAC & GCATTGCCAAAAGTTACCTAA \\
Phox 23 & GGGTATCGGTGCATCCCTAAA & GGCGTAGCAATCATTATACCT \\
Pho 30 & TTGAGTGGATGGTGCTTGTA & CAGGAAAGTGCCAGCATACAC \\
& TCCCTCACTGTGCCCTACA & GGAAACAACGGATTTCACATCA \\
& GTGAAGCATGGCATAGCACA & GAAACAACGGATTTCACATCA \\
\hline
\end{tabular}

\section{PCR amplification}

Samples of 20-100 ng genomic DNA extracted from 4 randomly selected fish belonging to Bledzewo populations and 4 from Kowalicha were used as templates in the PCR mixtures. Each PCR composition contained a $3 \mu \mathrm{L}$ TAQ buffer, $430 \mu \mathrm{mol}$ dNTP, 12 pmol of each primer, $0.3 \mathrm{U}$ Run Taq polymerase (A\&A Biotechnology), and was filled to $30 \mu \mathrm{L}$ with nuclease-free water. A PCR protocol was started with an initial denaturation at $94^{\circ} \mathrm{C}$ for $3 \mathrm{~min}$, followed by 34 cycles of denaturation at $94^{\circ} \mathrm{C}$ for $30 \mathrm{~s}$, annealing for $30-45 \mathrm{~s}$ and elongation at $64^{\circ} \mathrm{C}$ for $30-45 \mathrm{~s}$, and ended by a final elongation at $64^{\circ} \mathrm{C}$ for $35 \mathrm{~min}$. The annealing temperature was determined empirically for each locus based on a series of tests carried out at temperatures between $50^{\circ}$ and $67^{\circ} \mathrm{C}$ performed in Mastercycler Gradient thermal cyclers (Eppendorf, Germany) with a gradient of $1^{\circ} \mathrm{C}$. The highest temperature that allowed ample PCR product while preventing stutter bands and other 
unspecific fragments as much as possible was recorded as optimal for a given set of primers. The PCR product was verified by agarose gel electrophoresis and stained using ethidium bromide.

The primer sets providing successful amplification were reordered. In the new pairs of primers, the forward oligonucleotides were 5'-end labeled with phosphoramidite dyes (6FAM, VIC, NED, or PET) to enable genotyping of the PCR product using the Applied Biosystems 3130 Genetic Analyzer. The amplifications performed during the previous optimization stage were repeated using labeled primer sets and the electrophoretic profiles of obtained fragments as well as possible stutter bands were inspected during automatic capillary electrophoresis and analyzed by the Genemapper 3.0 software. The primer sets providing the PCR product with easily identifiable alleles of microsatellites were selected for amplification of the microsatellites obtained from the remaining DNA samples and applied in population studies.

\section{Amplification quality and genotyping}

The lengths of amplified DNA fragments were determined using an Applied Biosystems 3130 Genetic Analyzer against GS500LIZ size standards. The quality of the obtained PCR product was assessed using the following scale: $\mathrm{U}, \mathrm{U}_{\mathrm{ST}}, \mathrm{ST}$, and NA. Only primers enabling clear amplification of microsatellites from DNA samples derived from all investigated fish were marked as useful (U). Samples with minor stutter bands surrounding microsatellite fragments were marked as $\left(\mathrm{U}_{\mathrm{ST}}\right)$. Both $\mathrm{U}$ and $\mathrm{U}_{\mathrm{ST}}$ amplification quality enabled clear identification of true microsatellite alleles among the obtained bands. Samples with considerable stutter and multiple bands hindering the identification of true microsatellite bands were marked as stutter (ST). Samples not amplifying or amplifying from few samples were marked as "no amplify" (NA). Due to the possible confusion between true microsatellite alleles and other fragments, bands having no trace of a weaker band 1 repeat below were included in the category NA, even when only 1 or 2 bands were observed. Due to possible confusion with primer/dimer fragments, the bands shorter than $70 \mathrm{bp}$ were scored as NA even when 1 difference in their lengths between samples was detected and traces of a weaker band 1 repeat below were observed.

\section{Statistical analysis}

To successfully amplify microsatellites (amplification quality $\mathrm{U}_{\text {and }} \mathrm{U}_{\mathrm{ST}}$ ), the number of alleles observed per locus and in populations was computed by the MSA software (Dieringer and Schlötterer, 2003). Tetrasomic locus $\mathrm{Ca} 4$ was divided into 2 independent inherited isoloci to accommodate it to the requirements of microsatellite alleles and the Arlequin software.

The exact Hardy-Weinberg (HW) test (Guo and Thompson, 1992) was used to test deviations from HW equilibrium. The test was performed separately for each locus in all populations (Guo and Thompson, 1992). The number of steps in the Markov chain equaled $1,000,000$ and the number of dememorization steps equaled 100,000 and was computed by the Arlequin 3.0 software (Excoffier et al., 2005).

\section{RESULTS}

Of the total 15 primer pairs tested, 6 amplified successfully (amplification quality $U$ and $\mathrm{U}_{\mathrm{ST}}$ ). The optimal annealing temperature for each of them is given in Table 2. The loci Z9878, Z10363, Z13419, Ca4, and Ca12 were proven to be polymorphic in all populations, but locus 
Ca3 was polymorphic in only 3 of 6 populations (Table 3 ). Deviations from the HW equilibrium were detected at locus $Z 9878$ in all populations and at $\mathrm{Ca} 12$ in the Bledzewo population. The loci Z9878, Z10363, Z13419, Ca3, and Ca12 were disomic, but Ca4 was identified as tetrasomic. The amplification with 3 other primer sets, Z14008, Phox23, and Phox30, was not clear because of stutter bands. Locus Z9523 was amplified successfully in fish from Bledzewo and Kowalicha, but it was scored as NA because the obtained PCR product was very short (between 60 and $75 \mathrm{bp}$ ), approximately that of primer/dimer fragments. The amplification of locus $Z 8356$ from Bledzewo and Kowalicha samples derived many random bands in the range of 112 and $241 \mathrm{bp}$ and therefore this primer set was qualified as NA. Amplification of loci Z9068, Z11841, Z11841, CA5, and CA11 failed NA because no PCR product was observed in the range of 70-400 bp.

\begin{tabular}{|c|c|c|}
\hline Locus & Optimal annealing temperature & Amplification quality \\
\hline Z8356 & - & NA \\
\hline Z9068 & - & NA \\
\hline Z9523 & - & NA \\
\hline$Z 9878$ & 55 & $\mathrm{U}_{\mathrm{ST}}$ \\
\hline Z10362 & 54 & $\mathrm{U}_{\mathrm{ST}}^{\mathrm{IT}}$ \\
\hline Z11841 & - & $\mathrm{NA}$ \\
\hline Z13419 & 56 & $\mathrm{U}$ \\
\hline Z14008 & - & ST \\
\hline $\mathrm{Ca} 3$ & 56 & $\mathrm{U}$ \\
\hline $\mathrm{Ca} 4$ & 56 & $\mathrm{U}_{\mathrm{ST}}$ \\
\hline $\mathrm{Ca} 5$ & - & $\mathrm{NA}$ \\
\hline Call & - & NA \\
\hline Cal2 & 57 & $\mathrm{U}$ \\
\hline Phox23 & - & ST \\
\hline Phox30 & - & ST \\
\hline
\end{tabular}

$\mathrm{U}=$ useful; $\mathrm{U}_{\mathrm{ST}}=$ useful with minor stutter; $\mathrm{ST}=$ major stutter/multiple bands; NA = no amplify.

Table 3. Number of alleles detected at loci Z9878, Z10362, Z13149, Ca3, Ca4, and Ca12 in Bledzewo, Kowalicha, Siedliszcze, Sośniak, Mikołajki Pomorskie (Pom.), and Podpakule populations.

\begin{tabular}{|c|c|c|c|c|c|c|c|c|c|c|c|c|c|}
\hline \multirow[t]{2}{*}{ Locus } & \multicolumn{2}{|c|}{ Bledzewo } & \multicolumn{2}{|c|}{ Kowalicha } & \multicolumn{2}{|c|}{ Siedliszcze } & \multicolumn{2}{|c|}{ Sosniak } & \multicolumn{2}{|c|}{ Mikolajki Pom. } & \multicolumn{2}{|c|}{ Podpakule } & \multirow{2}{*}{$\begin{array}{c}\text { No. of } \\
\text { alleles across } \\
\text { populations }\end{array}$} \\
\hline & $\begin{array}{l}\text { Size } \\
\text { range }\end{array}$ & $\begin{array}{l}\text { No. of } \\
\text { alleles }\end{array}$ & $\begin{array}{c}\text { Size } \\
\text { range }\end{array}$ & $\begin{array}{l}\text { No. of } \\
\text { alleles }\end{array}$ & $\begin{array}{c}\text { Size } \\
\text { range }\end{array}$ & $\begin{array}{l}\text { No. of } \\
\text { alleles }\end{array}$ & $\begin{array}{c}\text { Size } \\
\text { range }\end{array}$ & $\begin{array}{l}\text { No. of } \\
\text { alleles }\end{array}$ & $\begin{array}{c}\text { Size } \\
\text { range }\end{array}$ & $\begin{array}{l}\text { No. of } \\
\text { alleles }\end{array}$ & $\begin{array}{c}\text { Size } \\
\text { range }\end{array}$ & $\begin{array}{l}\text { No. of } \\
\text { alleles }\end{array}$ & \\
\hline Z9878 & $105-121$ & $2 *$ & $105-121$ & $2 *$ & $105-121$ & $2 *$ & $105-121$ & $2 *$ & $105-121$ & $2 *$ & $105-121$ & $2 *$ & 5 \\
\hline$Z 10362$ & $109-119$ & 2 & $109-129$ & 3 & 103-109 & 2 & $109-119$ & 3 & $111-119$ & 2 & 103-119 & 3 & 5 \\
\hline$Z 13149$ & $192-206$ & 2 & $192-206$ & 2 & $192-206$ & 2 & $192-206$ & 2 & $192-206$ & 2 & $192-206$ & 2 & 2 \\
\hline $\mathrm{Ca} 3$ & $199-203$ & 2 & $199-219$ & 3 & 199 & 1 & 199 & 1 & 199 & 1 & 191-199 & 2 & 3 \\
\hline $\mathrm{Ca} 4$ & $78-90$ & 3 & $78-84$ & 3 & $84-90$ & 2 & $78-90$ & 4 & $78-90$ & 3 & 78-90 & 3 & 4 \\
\hline $\mathrm{Cal} 2$ & $218-254$ & $5^{*}$ & $218-258$ & 8 & $246-262$ & 4 & $242-258$ & 5 & $214-226$ & 2 & $214-242$ & 7 & 12 \\
\hline $\begin{array}{l}\text { No. of alleles } \\
\text { across loci }\end{array}$ & & 16 & & 21 & & 13 & & 17 & & 12 & & 19 & \\
\hline
\end{tabular}

*Deviation from Hardy-Weinberg equilibrium at $\mathrm{P}<0.0001$. Fragment size ranges are given in $\mathrm{bp}$.

\section{DISCUSSION}

Of the 15 primer sets developed for 3 cyprinid species tested, only 5 sets of primers (Z10363, Z13419, Ca3, Ca4, and Ca12) can be established as useful in various studies on lake 
minnow population genetics. These results confirmed the deviation from HW equilibrium at locus Z9878 reported by Holmen et al. (2005) in various species of cyprinids. We found that this was common for all lake minnow populations investigated in this study, which could limit the application of this locus in population genetics. The loci Z9878, Z10363, Z13419, Ca3, $\mathrm{Ca} 4$, and $\mathrm{Ca} 12$ proved to be amplifiable from DNA derived from various populations. The polymorphism of these microsatellites is relatively low, probably as a consequence of specific lake minnow biology, where considerable changes in population size are often observed.

Nine sets of primers were not suitable for amplification of the microsatellites from lake minnow DNA for the following reasons: stutter bands, randomly amplifying fragments, very short PCR product, or no amplification.

The genomes of cyprinid fish species differ in ploidy levels (Ohno et al., 1967). Some species are diploid while others are tetraploid and even hexaploid. The ploidy of lake minnows is unknown, but it seems that some tetrasomic or duplicated disomic regions including locus Ca4 may be present.

\section{ACKNOWLEDGMENTS}

Research supported by the Ministry of Science and Higher Education in Poland (Project \#NN304 324839 for 2010-2013).

\section{REFERENCES}

Dieringer D and Schlötterer C (2008). Microsatellite analyzer (MSA): a platform-independent analysis tool for large microsatellite data sets. Mol. Ecol. Notes 3: 167-169.

Dimsoski P, Toth GP and Bagley MJ (2000). Microsatellite characterization in central stoneroller Campostoma anomalum (Pisces: cyprinidae). Mol. Ecol. 9: 2187-2189.

Excoffier L, Laval G and Schneider S (2005). Arlequin (version 3.0): an integrated software package for population genetics data analysis. Evol. Bioinform. Online 1: 47-50.

Fopp-Bayat D (2002). Sturgeon genetics. The application of studies on polymorphism of the microsatellite DNA. Komunikaty Rybackie 2: 24-26.

Guo SW and Thompson EA (1992). Performing the exact test of Hardy-Weinberg proportion for multiple alleles. Biometrics 48: 361-372.

Holmen J, Vollestad LA, Jakobsen KS and Primmer CR (2005). Cross-species amplification of zebrafish and central stoneroller microsatellite loci in six other cyprinids. J. Fish Biol. 66: 851-859.

O’Connell M and Wright JM (1997). Microsatellite DNA in fishes. Rev. Fish Biol. Fish. 7: 331-363.

Ohno J, Muramoto J, Christian L and Atkin NB (1967). Dipliod-tetraploid relationship: A wide-range survey of crossspecies references among old-world members of the fish family Cyprinidae. Chromosoma 23: 1-9.

Primmer CR, Moller AP and Ellegren H (1996). A wide-range survey of cross-species microsatellite amplification in birds. Mol. Ecol. 5: 365-378.

Radtke G, Wolnicki J and Kaminski R (2011). Occurrence, threats and protection of the endangered lake minnow, Eupallasella percnurus (Pall.), in Pomorskie Voivodeship in Poland. Arch. Polish Fish. 19: 183-193.

Shimoda N, Knapik EW, Ziniti J, Sim C, et al. (1999). Zebrafish genetic map with 2000 microsatellite markers. Genomics 58: 219-232.

Spruell P, Hemingsen AR, Howell PJ, Kana N, et al. (2003). Conservation genetics of bull trout: Geographic distribution of variation microsatellite loci. Conserv. Genet. 4: 17-29.

Tong J, Wang Z, Yu X, Wu Q, et al. (2002). Cross-species amplification in silver carp and bighead carp with microsatellite primers of common carp. Mol. Ecol. Notes 2: 245-247.

Wolnicki J, Kaminski R and Sikorska J (2011). Occurrence, threats and active protection of the lake minnow, Eupallasella percnurus (Pall.), in Mazowieckie Voivodeship in Poland. Arch. Pol. Fish. 19: 209-216.

Zhao N, Ai W, Shao Z, Zhu B, et al. (2005). Microsatellite assessment of Chinese sturgeon (Acipenser sinensis Gray) genetic variability. J. Appl. Ichthyol. 21: 7-13. 